\title{
Особливості мікростанів викликаних потенціалів кори головного мозку в осіб із низькими показниками рівня уваги в результаті проходження альфа-тренінгу
}

\author{
Тетяна Качинська, Діана Василюк, Ольга Абрамчук
}

Волинський національний університет імені Лесі Українки, Луцьк, Україна Адреса для листування: Kachynska.Tatiana@vnu.edu.ua

Резюме. Мета дослідження полягала у виявленні впливу альфа-тренінгу на особливості мікростанів викликаної активності кори головного мозку в осіб із низькими показниками рівня уваги. Дослідження проведено на 7 особах (2 хлопці та 5 дівчат) віком 19-21 років із середнім та низьким рівнем уваги. Етапи дослідження: психологічне дослідження (тестування); сенсомоторне дослідження (тест «реакція на рухомий об’єкт»); нейрофізіологічне дослідження (нейрофідбек-тренінг, запис когнітивних викликаних потенціалів кори головного мозку). Використовуючи аналіз даних викликаних потенціалів кори головного мозку за особливістю мікростанів, виявили, що після 10 сеансів альфа-тренінгу сприйняття, обробка та контроль за прийняттям рішення здійснювалися із залученням передньої та задньої систем уваги. Тоді як до початку сеансів відзначено залучення лише передньої системи уваги за рахунок локалізації джерел активності в лобових ділянках кори головного мозку.

Ключові слова: мікростани, альфа-тренінг, джерела активності, увага.

\section{Changes in ERP microstates after alpha-training in people with low levels of attention}

\author{
Tetiana Kachynska, Diana Vasyluk, Olha Abramchuk \\ Lesia Ukrainka Volyn National University, Lutsk, Ukraine \\ Correspondence: Kachynska.Tatiana@ vnu.edu.ua
}

\begin{abstract}
The purpose of the study was to identify the effect of alpha-training on the characteristics of microstates caused by the activity of the cerebral cortex in people with low levels of attention. 7 volunteers 1921 years old ( 2 males and 5 females) with medium and low levels of attention participated in the neurofeedback-training. Stages of research: psychological research (testing); sensorimotor research (test "reaction to a moving object"); neurophysiological research (neurofeedback training, recording of cognitive evoked potentials of the cerebral cortex). Using the analysis of the data of the evoked potentials cerebral cortex by the feature of microstates, it was shown that after 10 sessions of alpha-training perception, processing and control of decision-making were carried out with the involvement of the anterior and posterior attention systems. Whereas before the beginning of the sessions, only the anterior attention system was involved due to the localization of sources of activity in the frontal areas of the cerebral cortex.
\end{abstract}

Keywords: microstates, alpha-training, sources of activity, attention.

\section{ВСТУП}

Враховуючи світові тенденції розвитку освіти, зазначимо, що все більшого поширення набувають інтеграційні процеси, виявлені в різноманітних формах спільного навчання, виховання та корекції для розвитку здорового населення. Відхилення та незначні зміни у фізичному або розумовому розвитку призводять до зниження перебігу будь-якого психічного процесу та його головної складової - уваги, яка $\epsilon$ однією 3 найважливіших психічних функцій, що забезпечує оптимізацію процесів навчання і виховання [1]. Вона може змінювати свою активність протягом доби [2], має багато властивостей, які згруповують 
Lesia Ukrainka Eastern European National University Scientific Bulletin Series:

Biological Sciences, 2020, 2 (390)

залежно від того, спрямована вона на один або кілька об'єктів. До властивостей, що характеризують увагу, спрямовану на один об'єкт, зараховують обсяг, концентрацію (вибірковість), стійкість. До властивостей, що характеризують увагу, спрямовану на кілька об'єктів, належать переключення і розподіл. Як динамічний процес, вона в однієї і тієї ж самої людини може змінюватись залежно від багатьох факторів, впливаючи на поведінкові та психофізіологічні особливості людини [3]. Тому необхідним $є$ пошук методів психокорекції для покращення рівня уваги та психоемоційного стану.

Одним із таких методів $\epsilon$ нейрофідбек метод психокорекції функціонального стану людини, який грунтується на застосуванні біологічного зворотного зв'язку (БЗ3) за нейрофізіологічними параметрами [4]. Суть Б33 зводиться до вдосконалення нормальних і корекції порушених функцій організму за допомогою інструментального навчання спеціалізованих навичок саморегуляції та самоконтролю поточного функціонального стану. Тобто, досліджуваний шляхом психічної релаксації, фізичного розслаблення чи, навпаки, концентрації уваги свідомо контролює свій психічний стан за допомогою БЗЗ, який реєструється ЕЕГ-апаратурою, що інформує про його амплітудно-частотні характеристики $[5,6]$.

На сьогодні показано, що електрична активність головного мозку людини може бути представлена у вигляді почергової зміни невеликих ділянок ЕЕГ із специфічними характеристиками. Вважається, що такі ділянки відображають певні характерні стани активності головного мозку людини, які називаються мікростанами. При цьому статистичні та топографічні характеристики мікростанів схожі в різних осіб під час однакових типів розумової активності. У цьому сенсі мікростани можуть бути електрофізіологічними корелятами періодів стабільних просторових моделей, запропонованих у глобальній теорії робочої зони [7] або стану, які, прийшовши і вийшовши 3 фокусу, могли б досягти різних рівнів свідомості, як описано [8], і інформація, що передається між станами, може кодувати плавний перехід від одного процесу до іншого.

Основний принцип виділення мікростанів 3 ЕЕГ - збереження статистичних характеристик ЕЕГ протягом певного часу (від декількох десятих секунди до декількох секунд). Різкі зміни статистичних характеристик ЕЕГ відображає перехід від одного мікростану до іншого. Припускають, що суб'єктивно окремий мікростан сприймається як окремий момент психічної активності, тому мікростани ще називають «квантами» психічної активності. Різні типи активності можуть характеризуватися різними типами мікростанів. Концепція «мікростану когнітивної функції (пізнання)» підтверджена електрофізіологічним спостереженням Лемана та колег [9], за яким дана конфігурація глобального електричного поля шкіри голови (так звана топографія), виміряна багатоканальною ЕЕГ, залишається стабільною протягом $\approx 100$ мсек, потім перемикається на нову конфігурацію. Команда Lehmann висунула гіпотезу, що ці широкосмугові ЕЕГ «мікростани» $\epsilon$ будівельними блоками людського пізнання «атоми думки» [7]. Вивчення мікростанів кори головного мозку в осіб із низьким рівнем уваги під час альфа-тренінгу $\epsilon$ досить фрагменттарними. Спроба дослідити особливості мікростанів та їх динаміку в процесі нейрофідбек-тренінгу надасть можливість отримати нову інформацію про залучення кори головного мозку та окремих іiі ділянок до процесу корекції психічних функцій.

Тому мета дослідження - виявити вплив альфа-тренінгу на особливості мікростанів викликаної активності кори головного мозку в осіб із низькими показниками рівня уваги.

\section{КОНТИНГЕНТ І МЕТОДИ ДОСЛІДЖЕНЬ}

Дослідження проведено на 7 особах (2 хлопці та 5 дівчат) віком 19-21 років, праворуких, здорових, із середнім та низьким рівнем уваги. Участь досліджуваних у експерименті передбачала їх добровільну згоду щодо участі в обстеженні. Вони були ознайомлені із процедурою нейрофідбектренінгу. Дослідження проводили відповідно до Конвенції Ради Європи «Про захист прав людини i людської гідності у зв'язку 3 застосуванням досягнень біології та медицини», Конвенції про права людини та біомедицину (ETS No. 164) від 04.04.1997 p. i Гельсінкської декларації Всесвітньої медичної асоціації (2008р.). Обстеження проводили в робочі дні тижня з 10:00 до 13:00 год. Перед записом ВП кори головного мозку опитували обстежуваних про наявність у них черепномозкових травм, стан здоров'я на момент дослідження. У разі виявлення вищеперерахованих особливостей обстеження не проводилось. 


\begin{tabular}{lllr}
\hline \multicolumn{1}{c}{ Дослідження } & \multicolumn{1}{c}{ проходило } & в & \multicolumn{1}{c}{ три етапи: } \\
психологічне & дослідження & (тестування); \\
сенсомоторне & дослідження & (тест & «реакція на \\
рухомий & об’єкт»); & нейрофізіологічне \\
дослідження & (нейрофідбек-тренінг, & запис \\
когнітивних & викликаних & потенціалів & кори \\
головного мозку). &
\end{tabular}

Для визначення рівня уваги використовували психофізіологічні тести: таблиці «Шульте», вивчення рівня уваги за методикою П. Я. Гальперіна та С. Л. Кабильницької, тест на визначення обсягу уваги [10].

Процедура нейрофідбек-тренінгу та вивчення особливостей електричної активності кори головного мозку відбувалося в лабораторії «Вікової нейрофізіології» кафедри фізіології людини і тварин.

Нейрофізіологічний етап дослідження передбачав процедуру 3 10-ти сеансів альфатренінгу та запис викликаних потенціалів кори головного мозку в парадигмі Р300 після 1-го, 5го та 10-го сеансів нейрофідбек-тренінгу.

Процедуру альфа-тренінгу проводили за допомогою програмно-апаратного комплексу «НейроКом» (XАI МЕДИКА, м. Харків) зі спеціально створеним у ньому модулем «БЗ3тренінг». Було проведено десять 10-хвилинних сеансів альфа-тренінгу. Для реалізації принципу Б33 досліджуваний контролював положення вибраного об'єкту на моніторі, формуючи свій психоемоційний стан.

Запис викликаної активності кори головного мозку здійснювали за допомогою програмноапаратного комплексу «НейроКом» (м. Харків, XАІ МЕДИКА). Реєстрацію ВП проводили за загальновизнаною методикою ЕЕГ - системою “10-20\%” від 19-ти електродів. Досліджуваний перебував у екранованій, світло- i звукоізольованій кімнаті сидячи, в стані спокою.

Стимуляцію здійснювали шляхом представлення на моніторі, який знаходився на відстані 1-1,5 м від пацієнта, картинок із різним перцептивним змістом. Процедура експерименту включала реєстрацію потенціалів, пов'язаних із подіями, в парадигмі Р300, де досліджуваний повинен був реагувати, натискаючи на кнопку пульта пацієнта, тим самим фіксуючи правильність своєї відповіді на слова живої природи. Як незначимі стимули були використані слова неживої природи. Було подано 50 значимих i 110 незначимих стимулів, міжстимульний інтервал становив 11,5 сек. Надалі було проведено ICA-аналіз отриманих даних. ICA-компоненти 3 яскраво вираженими артефактними характеристиками та низькою достовірністю з наступної обробки були видалені.

Для визначення локалізації джерел незалежних компонентів викликаних потенціалів та мікростанів кори головного мозку використовувалася sLORETA [11]. Для кожного незалежного компонента на підставі розрахованих коефіцієнтів, що визначають вплив кожного джерела на електроди, будувалося зображення sLORETA 3 урахуванням координатної сітки електродів i сферичної тришарової моделі головного мозку, підігнаній під стандартний атлас мозку людини.

Статистичу обробку проводили за допомогою методів варіаційної статистики, дані обчислювали в програмному пакеті Loreta, MegaStat або безпосередньо в MS Excel 2019. Достовірність відмінностей показників між процедурами альфа-тренінгу, у випадку параметричної вибірки, визначали за допомогою критерію Стьюдента, для змінних вибірок, що не мали нормального розподілу, використовували непараметричний критерій Вілкоксона $\square 12 \square$.

\section{РЕЗУЛЬТАТИ ДОСЛДЖЕННЯ}

Концентрація уваги, яку визначали за таблицями «Шульте», у досліджуваних знаходилася на достатньому рівні до проходження процедур нейрофідбек-тренінгу

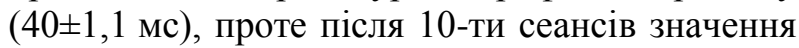
досліджуваного показника зменшилися $(37 \pm 1,6$ мс), що вказує на покращення концентрації уваги (рис. 1).

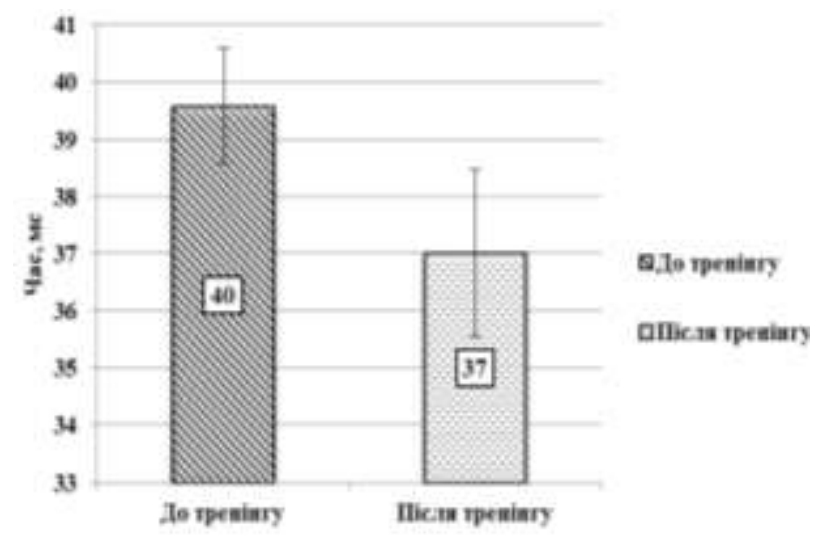

Рис. 1. Зміна показників уваги до та після проходження альфа-тренінгу за табличями «Шульте»

Порівнявши показники рівня уваги до та після проведення тренінгу (за методикою 
Особливості мікростанів викликаних потениіалів кори головного мозку в осіб із низькими показниками рівня vваги в результаті проходження альда-тренінгу

П. Я. Гальперіна $\quad$ і С. Л. Кабильницької) та обсяг уваги, можна зробити висновок, що досліджувані 3 низьким та середнім рівнем досліджуваних показників досягли значних результатів. Так, після проходження 10-ти сеансів нейрофідбек-тренінгу в досліджуваних iз низьким рівнем уваги та малим рівнем іiі обсягу спостережено покращення результатів і зафіксовано середній рівень уваги та ії обсяг. У досліджуваних із середнім рівнем уваги та iii обсягом зафіксовано високий рівень уваги та їі обсяг.

Проведений нами аналіз мікростанів та локалізації джерел активності під час класифікації значимості стимулів до початку сеансів альфа-тренінгу виявив шість мікростанів у корі головного мозку, перебування в яких надало можливість здійснити аналіз інформації та прийняти рішення про значимість стимулу. Так, $15 \%$ часу описувалося мікростаном А, $8 \%$ - мікростаном B, 33\% - мікростаном C, 37\% - мікростаном G та 7\% - мікростаном F. Мікростан А (табл. 1.) описувався активністю в межах верхньої лобової закрутки, де розміщено 10 поле за Бродманом, що бере участь у формуванні стратегічних процесів, відновленні необхідних спогадів та управлінні функціями [13].

Таблиия 1

Мікростани та локалізація джерел викликаної активності кори головного мозку, що їх описує, до початку сеансів альфа-тренінгу в осіб із низьким рівнем уваги

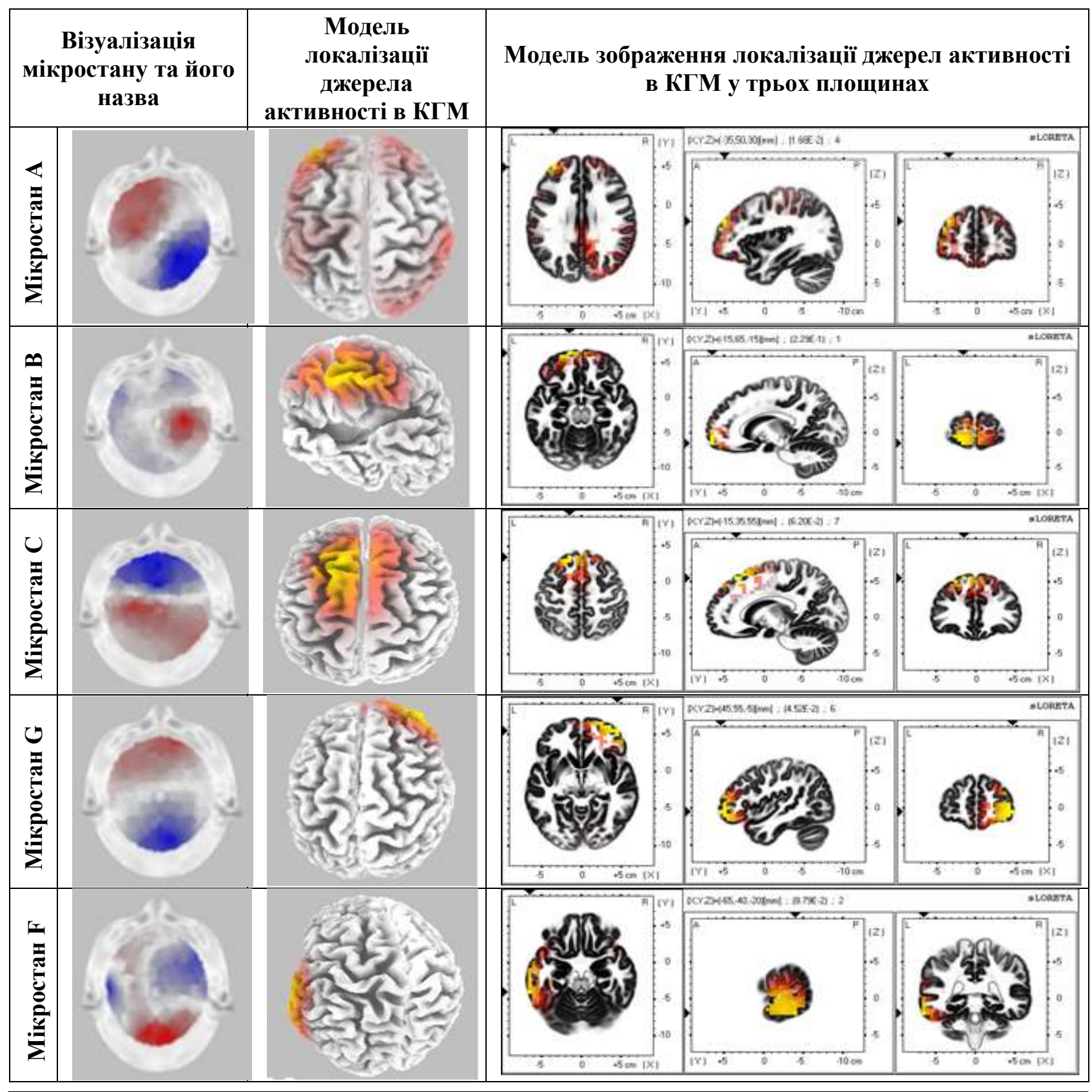



імені Лесі Українки. Серія: Біологічні науки, 2020, 2 (390)

Мікростан В описував функціональний стан кори головного мозку лише $8 \%$ часу від загального процесу виконання завдання 3 високою активністю в межах верхньої лобової закрутки, що відповідає 11 полю за Бродманом (табл. 1). Перебування в мікростані С (табл. 1) (зазначено $33 \%$ часу) характеризувалося локалізацією джерел активності в межах верхньої лобової закрутки, що відповідає 8 та 10 полям за Бродманом. Мікростан G (табл. 1) описував стан кори головного мозку найбільшу кількість часу - 37\% та характеризувався локалізацією джерела активності в межах верхньої та нижньої лобової закрутки правої півкулі, що відповідає 10 та 47 полям за Бродманом. Імовірно, 47 поле, яке бере участь в обробці синтаксису усної мови [13], на основі взаємодії із 10 полем, що здійснює контроль в управлінні реакції на стимули, дало змогу розпізнати значимий стимул.

Найменшу кількість часу мозок перебував у мікростані $\mathrm{F}$ - лише $7 \%$ (табл. 1), що описується активністю лівої бічної скроневої закрутки та відповідає 21 полю за Бродманом. Це поле відіграє певну роль в обробці слухових імпульсів і мовленні, а оскільки процедура експерименту не передбачала сприйняття звукових сигналів, тому виявлена активність [14], можливо, пов'язана із загальною фоновою звуковою стимуляцією.

Проведений нами аналіз мікростанів та локалізації джерел активності під час класифікації значимості стимулів після 5-ти сеансів альфа-тренінгу виявив чотири мікростани в корі головного мозку, перебування в яких дало змогу здійснити аналіз інформації та прийняти рішення про значимість стимулу. Так, $67 \%$ часу описувалося мікростаном G, $15 \%$ - мікростаном C, 9,5\% мікростаном $\mathrm{E}, \quad 8,5 \%$ - мікростаном $\mathrm{F}$. Мікростан $\mathrm{G}$ (табл. 2) описувався активністю в прецентральній та постцентральній звивинах кори головного мозку, де розміщено 6 та 7 поля за Бродманом. 7 поле відповідає за

Таблиця 2

Мікростани та локалізація джерел викликаної активності кори головного мозку, що їх описує, після 5 сеансів альфа-тренінгу в осіб із низьким рівнем уваги

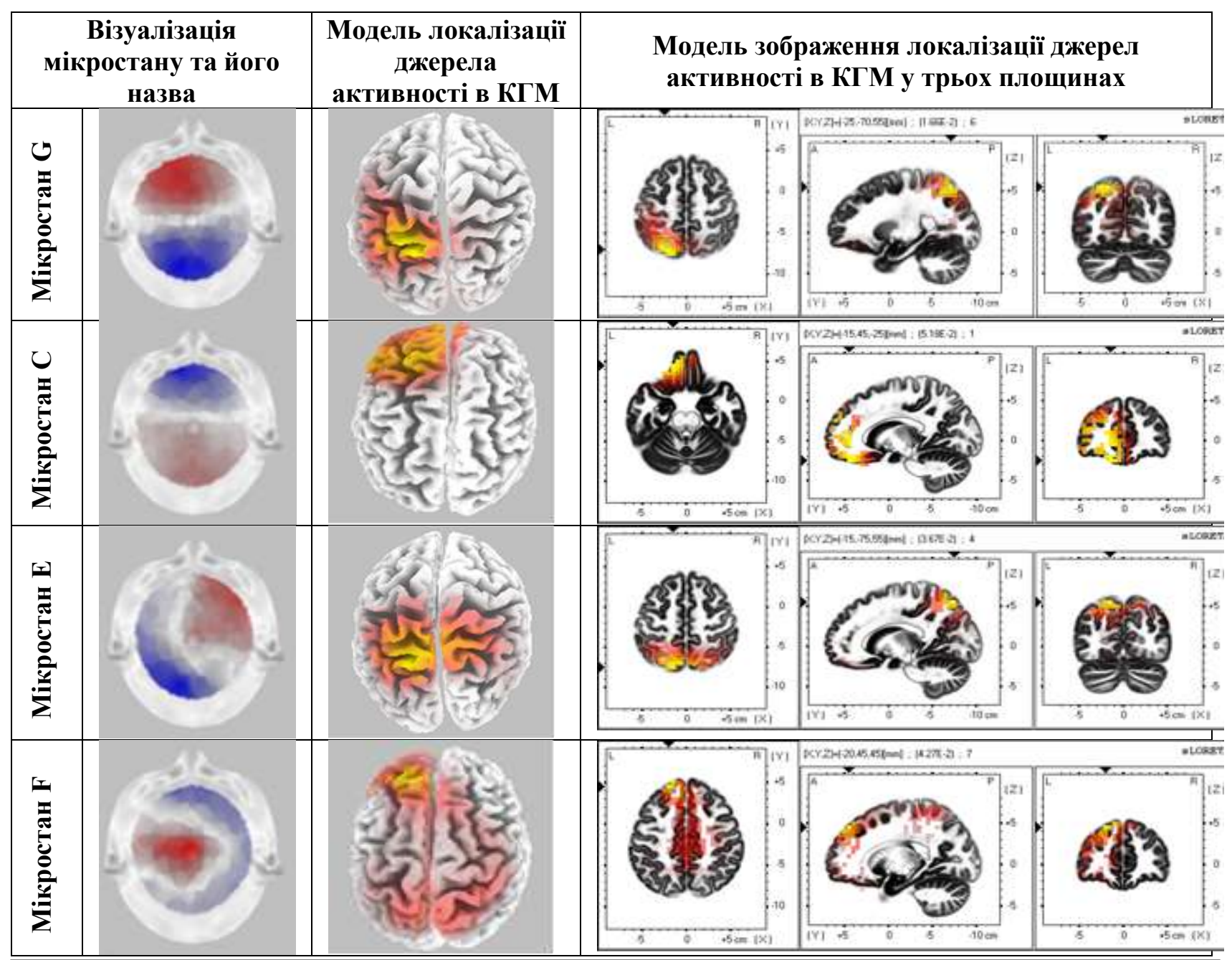

Качинська Т., Василюк Д., Абрамчук О.., 2020 
Особливості мікростанів викликаних потенціалів кори головного мозку в осіб із низькими показниками рівня уваги в результаті проходження альфа-тренінгу

розпізнання об'єктів та відчуття, що з ними пов'язані, тоді як 6 поле відповідає за формування планів та послідовність дій [14].Перебування в мікростані С (табл. 2) (відзначено $15 \%$ часу) характеризувалося локалізацією джерел активності в правій лобовій ділянці, що відповідає 11 полю за Бродманом.

Мікростан Е (табл. 2) описував стан кори головного мозку 9,5\% часу та характеризувався локалізацією джерела активності в межах верхньої тім'яної закрутки, що відповідає 7 полю за Бродманом. Найменшу кількість часу мозок перебував у мікростані $\mathrm{F}$ - лише 8,5\% (табл. 2), що має активність верхньої лобової закрутки та відповідає 8 полю за Бродманом. Це поле активується, коли досліджувані відчувають невизначеність, і по мірі зростання невизначеності зростає й активація [13]. Очевидно 5 сеанс $є$ ключовим, що дає змогу скоригувати тактику мозкових процесів, економізувати та автоматизувати певний вид діяльності.

Проведений аналіз мікростанів та локалізації джерел активності під час класифікації значимості стимулів після 10-ти сеансів альфа-тренінгу виявив чотири мікростани в корі головного мозку, перебування в яких надало можливість здійснити аналіз інформації та прийняти рішення про значимість стимулу. Так, 28\% часу описувалося мікростаном В, 44\% - мікростаном G, $14 \%$ мікростаном C, $14 \%$ - мікростаном F. Мікростан G (табл. 3) описувався активністю лобової кори, де розміщено 9 та11 поля за Бродманом.

Мікростан В (табл. 2) описував стан кори головного мозку 28\% часу та характеризувався локалізацією джерела активності в межах правої нижньої лобової закрутки, що відповідає 47 полю за Бродманом та бере участь в обробці синтаксису усної мови. Мікростан С (табл. 3) описував стан кори

Таблиия 3

Мікростани та локалізація джерел викликаної активності кори головного мозку, що їх описує, після 10 сеансів альфа-тренінгу в осіб із низьким рівнем уваги

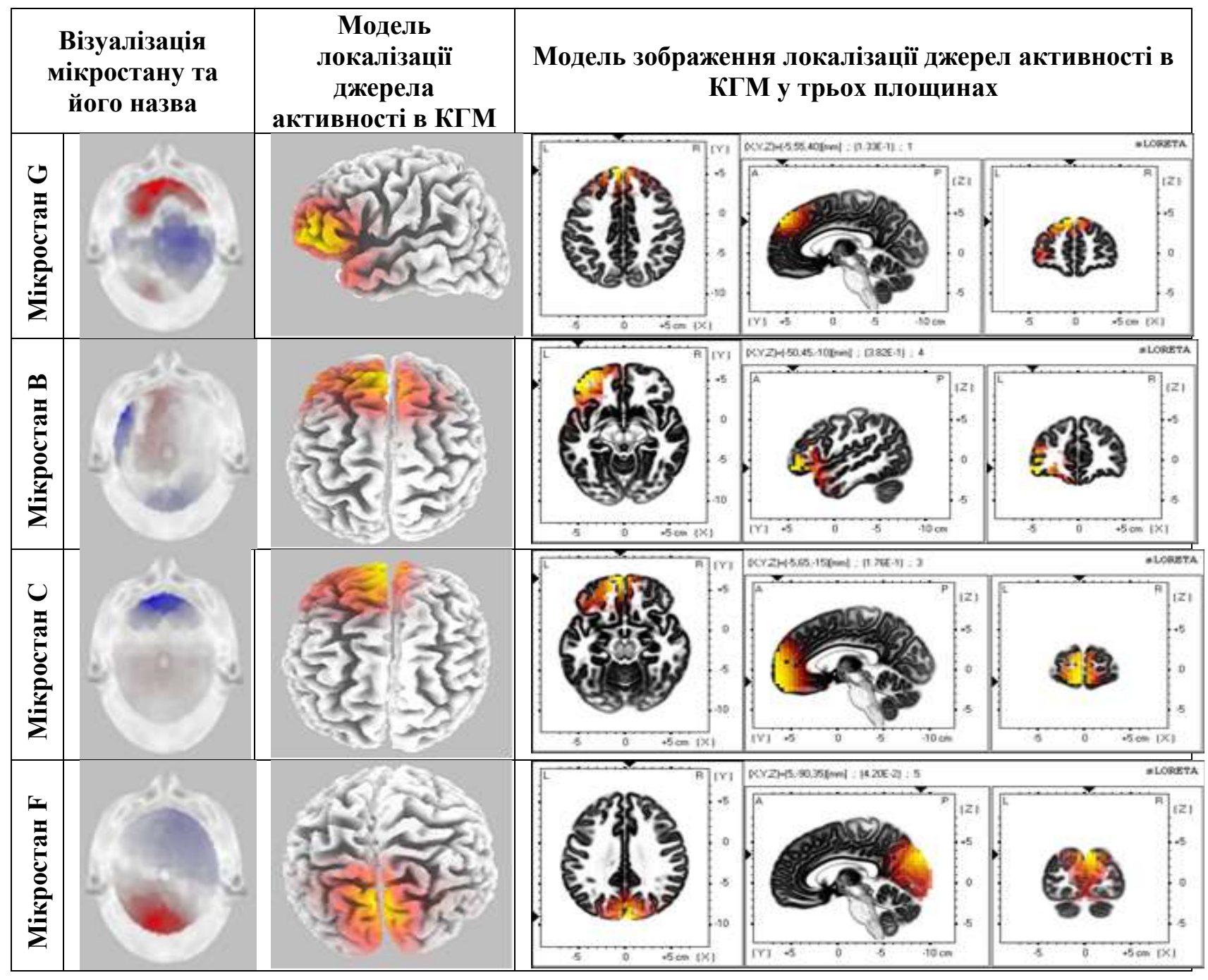


головного мозку 14\% часу та характеризувався локалізацією джерела активності в межах бічної лобової закрутки, що відповідає 11 полю за Бродманом. 14\% часу описувався стан кори головного мозку мікростаном $\mathrm{F}$ та характеризувався локалізацією активності в межах потиличних ділянок кори головного мозку, що відповідає 19 полю за Бродманом, де відбувається оцінка побаченого.

Мікростан В (табл. 3) описував стан кори головного мозку 28\% часу та характеризувався локалізацією джерела активності в межах правої нижньої лобової закрутки, що відповідає 47 полю за Бродманом та бере участь в обробці синтаксису усної мови.

Мікростан С (табл. 3) описував стан кори головного мозку 14\% часу та характеризувався локалізацією джерела активності в межах бічної лобової закрутки, що відповідає 11 полю за Бродманом. 14\% часу описувався стан кори головного мозку мікростаном $\mathrm{F}$ та характеризувався локалізацією активності в межах потиличних ділянок кори головного мозку, що відповідає 19 полю за Бродманом, де відбувається оцінка побаченого.

\section{ОБГОВОРЕННЯ}

Ми виявили, що частота виникнення специфічних топографій головного мозку, просторово пов'язаних із візуальними й виконавчими мережами, пов'язана 3 G мікростанами. Більше того, зміни в G мікростанах у процесі альфа-тренінгу обернено корелюються зі змінами у властивостях мікростанів, що свідчить про те, що зміни в динаміці мереж мозку $є$ поведінковими. На нашу думку, когнітивна підготовка, яка збільшує $\mathrm{G}$ мікростани, призводить до заднього зрушення в топографії та появи мікростану $\mathrm{F}$ y потиличних ділянках. Ці результати підкреслюють роль альфа-тренінгу для корекція та покращення змінних електричних станів мозку у відповіді на когнітивне навантаження із залученням уваги.

Передня система уваги (в медіальній фронтальній ділянці) відповідальна за формування уваги до дії i бере участь у семантичних операціях, які призводять до вибору правильного рішення, в той час як задня (просторово зорова система уваги) реалізує більш прості завдання, пов'язані з контролем сприйняття зорової інформації або іï уявного уявлення $[15,16]$. Зазначений механізм сприйняття, обробки та контролю за прийняттям рішення ми виявили після 10 сеансів альфа-тренінгу. Тоді як до початку сеансів відзначено залучення лише передньої системи уваги за рахунок локалізації джерел активності у лобових ділянках кори головного мозку. Отже, альфа-тренінг має позитивний вплив на механізми уваги та можливість корекції електричної активності кори головного мозку 3 рівня більшої генералізованості мозкових процесів до рівня локальної активності окремих ділянок мозку для більшої автоматизації когнітивних процесів та легкості у їх реалізації.

\section{ВИСНОВКИ}

1. У процесі проходження 10-ти сеансів нейрофідбек-тренінгу в осіб із низьким рівнем уваги та малим рівнем іiі обсягу було спостережено покращення результатів i зафіксовано середній рівень уваги та їі обсяг.

2. Аналіз мікростанів та локалізації джерел активності під час класифікації значимості стимулів до початку сеансів альфа-тренінгу виявив шість мікростанів із локалізацією джерел активності в межах лобових ділянок кори головного мозку.

3. Аналіз мікростанів та локалізації джерел активності під час класифікації значимості стимулів після 10 сеансів альфа-тренінгу виявив чотири мікростани 3 локальним розміщенням джерел активності як у передньотак і задньоасоціативних структурах мозку.

\section{ЛIТЕРАТУРА}

1. Шорохова, В. Увага як чинник успішного навчання дітей із порушеннями психофізичного розвитку в інклюзивному класі. Нова педагогічна думка: науково-методичний журнал; 2011, № 4, т. 68, 74-77.

2. Григорьева, Л. П. Формирование механизмов внимания при сенсорно-перцептивном дефиците (часть II). Дефектология; 2002, № 1, 3-17.

3. Иваницкий, А. М.; Ильюченко, И. Р.; Иваницкий, Г. А. Избирательное внимание и память - вызванные потенциалы при конкуренции зрительных и слуховых словесных сигналов. Журн. высш. нервн. деятельности; 2003, т. 53, № 5, 541551.

4. Прохорова, Ж. В.; Долгих, В. В.; Полянков, В. М. и др. Биологическая обратная связь в коррекции психоэмоциональной сферы подростков c эссенциальной артериальной. URL: http://cyberleninka.ru

5. Bazanova, O. EEG Alpha Activity Enhances as a Result of Heart Rate Biofeedback Game Training. Applied Psychophysiology and Biofeedback; 2011, 36, 4, 293. 
Особливості мікростанів викликаних потенціалів кори головного мозку в осіб із низькими показниками рівня уваги в результаті проходження альфа-тренінгу

6. Базанова, О. М.; Штарк, М. Б. Биоуправление в оптимизации музыкальной деятельности. Бюллетень СО РАМН; 2004, № 3, 114-122.

7. Lehmann Hubert. Legal Concepts in a Natural Language Based Expert System. Ratio Juris; 1990, Vol. 3 (2), 245-253.

8. Koenig, T.; Prichep, L.; Lehmann, D.; Sosa, P. V.; Braeker, E.; Kleinlogel, H.; Isenhart, R.; John, E. R. Millisecond by millisecond, year by year: normative EEG microstates and developmental stages. Neuroimage; 2002, 16, 1, 41-48.

9. Lehmann, D.; Ozaki, H. EEG alpha map series: brain micro-states by space-oriented adaptive segmentation. EEG and Clin Neurophysiol; 1987, Vol. 67, 271-285.

10. Козляковський, П. А. Загальна психологія: навч. посібник: В 2 т. 2-ге вид., доп. і переробл. Вид-во МДГУ ім. П. Могили: Миколаїв; 2004, т. II, 240.
11. Pascual-Marqui, R. D. Standardized low resolution brain electromagnetic tomography (sLORETA): technical details. Methods \& Findings in Experimental \& Clinical Pharmacology; 2002, Vol. 24, 5-12.

12. Реброва, О.Ю. Статистический анализ медицинских данныхx. Информполиграф: Москва; 2002, 305.

13. Лурия, А.Р. Высшие корковые функции человека. Питер: СПб; 2019, 768.

14. Хомская, Е.Д. Нейропсихология, 4-е издание. Питер: СПб; 2008, 496.

15. Posner, I. Michael Orienting of Attention: Then and Now. Quarterly Journal of Experimental Psychology; 2016, Vol. 69, 10, 1864-1875.

16. Мачинская, Р. И. Нейрофизиологические механизмы произвольного внимания. Журнал высшей нервной деятельности; 2003, т. 53, № 2, 133-151. 